\title{
Pola Kerusakan Kinerja Fisik Komponen Atap Bangunan Rumah Susun Sederhana di Jakarta
}

\section{Andi Harapan}

Departemen Arsitektur, Universitas Komputer Indonesia, Mobile: 081321328844

Email: andi.harapan@email.unikom.ac.id

\begin{abstract}
INFORMASI ARTIKEL
Abstract: Roof is a part of building components which has many problems on encouraging building performance. Degradation of roof component accordingly can cause degradation of other building components. The degradation of roof component can be observed at low cost multi-storey housing projects (Rumah susun sederhana) in the capital city of Jakarta. Roof component which is planned to have 10 to 15 years technical life, has deteriorated halfway of its age. The degradation of roof component is not only affected by quality of material, but also by other factors, including: workmanship, design quality, maintenance quality, in used quality, and environment quality. Pattern of degradation of roof component and its causal factors at 14 low cost multi-storey housing projects in Jakarta will be discussed in this article. This paper is aimed to elaborate the degradation of technical performance of roof system at low cost multi-storey housing projects (Rumah susun sederhana) in the capital city of Jakarta, to acknowledge the variable of the degradation factors and how-to maintenance of its.
\end{abstract}

Keywords: Building Performance, Degradation, Roof Component, Low Cost Multi-Storey Housing

Abstrak: Atap merupakan salah satu komponen bangunan yang banyak memberikan masalah terhadap kinerja fisik suatu bangunan. Kerusakan pada komponen atap akan mengakibatkan kerusakan pada komponen bangunan lainnya. Kondisi ini dapat diamati pada rumah susun sederhana di Jakarta, baik yang sifatnya sewa maupun sewa-milik. Atap yang direncanakan berumur 10-15 tahun, umumnya sudah mengalami kerusakan fisik yang signifikan (harus diganti dan diperbaiki) pada setengah usia tersebut. Kerusakan atap selain disebabkan oleh kualitas material yang rendah, juga disebabkan oleh faktorfaktor lainnya, meliputi: kualitas pengerjaan, pengaruh desain bangunan, kualitas perawatan, kualitas penghuni, dan faktor lingkungan (iklim). Dalam artikel ini akan dibahas pola kerusakan atap dan faktor-faktor penyebabnya. Tujuan penelitian ini adalah untuk mengetahui kinerja teknis komponen atap bangunan rumah susun sederhana di Jakarta dan bagaimana melihat faktor-faktor penyebabnya untuk dilakukan perbaikan.

Kata Kunci: Kinerja Fisik Bangunan, Degradasi, Komponen Atap, Rumah Susun Sederhana

Article history:

Received ; 2021-04-15

Revised ; 2021-08-09

Accepted; 2021-09-03

\section{PENDAHULUAN}

Bangunan memiliki daur hidup yang terdiri dari berbagai tahapan, yakni tahap perencanaan, perancangan, konstruksi, dan penghunian (operasi dan perawatan). Kinerja suatu tahapan daur hidup akan berpengaruh signifikan terhadap kinerja tahap berikutnya dan terhadap kinerja bangunan secara keseluruhan (Preiser, 2005). De Wilde (2018) menyatakan bahwa apabila kinerja tahap perancangan buruk, maka dampaknya akan dirasakan pada tahap konstruksi dan tahap penghunian. Degradasi kinerja fisik komponen bangunan dapat terjadi karena dalam tahap perencanaan dan perancangan tidak dipertimbangkan faktor durabilitas komponen bangunan dan faktor pengaruh lingkungan (De Wilde, 2018; Mc Dulling, 2006).

Durabilitas adalah kemampuan bangunan atau komponen bangunan untuk berkinerja sesuai dengan fungsi yang dipersyaratkan selama periode waktu yang ditentukan (Oduyemi \& Okoroh, 2016; ISO 15686-1, 2000). Agar bangunan atau komponen bangunan mempunyai 
durabilitas yang baik, harus melihat beberapa factor yang menjadi menyebab (Oduyemi \& Okoroh, 2016; Hernández-Moreno, 2011), yaitu: 1) kualitas material, 2) kualitas desain, 3) kualitas pengerjaan, 4) kualitas perawatan, 5) kualitas lingkungan (iklim), dan 6) kualitas pengguna. Kualitas material harus dipertimbangan pada tahap perencanaan dan perancangan, sesuai dengan budget yang ditentukan untuk bangunan tersebut. Kualitas desain harus dipertimbangkan pada tahap desain, seperti misalnya penentuan detail suatu komponen bangunan. Kualitas pengerjaan atau kompetensi kontraktor dan tukang harus ditentukan pada tahap konstruksi. Kualitas lingkungan dan pengguna harus dipertimbangkan dan dikendalikan pada tahap penghunian. Mc Dulling (2005) menyatakan bahwa kualitas lingkungan dan pengguna akan menentukan laju degradasi bangunan atau komponen bangunan, sedangkan kualitas desain, material, pengerjaan, dan perawatan akan menentukan tingkat durabilitas bangunan atau komponen bangunan. ISO 15686-1 (2000) memberikan persamaan untuk menentukan kinerja fisik suatu bangunan atau komponen bangunan sebagai berikut: Kinerja Fisik $=\mathrm{f}$ (kualitas material, desain, pengerjaan, lingkungan (iklim), perawatan, penggunaan).

Menurut Trinius \& Sjöström (2005) dan Hernández-Moreno (2011), faktor-faktor yang mempengaruhi kinerja fisik bangunan atau komponen bangunan adalah sebagai berikut: A) Penyebab aspek kualitas material: jenis material, mutu material, kesesuaian dengan lingkungan, kesesuaian dengan sistem bangunan, dan biaya material. B) Penyebab aspek kualitas desain: kriteria desain, kualitas perancang, kesesuaian dengan lingkungan, kelengkapan informasi, koordinasi antar disiplin. C) Penyebab aspek kualitas pengerjaan: metode membangun, kualitas pekerja (tukang), kualitas kontraktor, kualitas pengawas, kelengkapan dokumen konstruksi (termasuk gambar kerja, tingkat kedetailan gambar, dll). D) Penyebab aspek kualitas lingkungan luar: temperatur, kelembaban, radiasi matahari, angin, hujan dan panas. E) Penyebab aspek kualitas pengguna: jumlah penghuni, aktivitas penghuni, kesadaran penghuni, kepranataan, vandalisme. F) Penyebab aspek kualitas desain : manual perawatan, intensitas perawatan, kualitas pengelola, biaya perawatan, administrasi perawatan. Dalam artikel ini akan dibahas pola kerusakan dan kinerja fisik komponen atap pada bangunan rumah susun sederhana di DKI Jakarta serta faktor-faktor penyebabnya, sebagai masukan bagi upaya optimalisasi kinerja rumah susun sederhana di Indonesia pada umumnya dan di DKI Jakarta pada khususnya.

\section{METODE PENELITIAN}

Penelitian ini dilakukan dengan 2 tahap, yaitu tahap 1 survei kondisi fisik komponen atap dan tahap 2 penyebaran kuesioner dan pengumpulan pendapat para ahli Rusunawa. Pengamatan dilakukan terhadap Rusunawa yang tersebar di DKI Jakarta (tabel 1), yang dipilih berdasarkan kerangka sampling purposif.

Tabel 1. Rumah Susun Sederhana Yang Diteliti DATA UMUM

\begin{tabular}{|c|c|c|c|c|c|c|c|c|}
\hline No & & 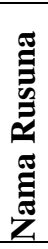 & 志 & & 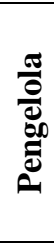 & 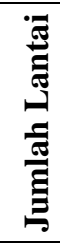 & 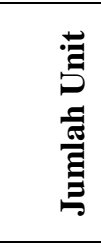 & 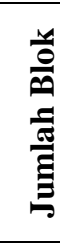 \\
\hline 1 & Bendungan Hilir II & & 12 & DKI & & 10 & 614 & 3 \\
\hline 2 & Tanah Abang & & 26 & Perumnas & & 4 & 960 & 60 \\
\hline 3 & Pasar Jumat & & 10 & Perumnas & & 10 & 120 & 2 \\
\hline 4 & Kemayoran & & 16 & Perumnas & & 5 & 2742 & 57 \\
\hline 5 & Cengkareng & & 12 & Perumnas & & 4 & 1728 & 10 \\
\hline 6 & Sindang Koja & & 8 & DKI & & 6 & 348 & 3 \\
\hline 7 & Budha Tzu Chi & & 5 & Swasta & & 5 & 1100 & 55 \\
\hline 8 & Klender & & 22 & Perumnas & & 4 & 1280 & 78 \\
\hline
\end{tabular}




\begin{tabular}{|c|c|c|c|c|c|c|c|c|}
\hline \multicolumn{9}{|c|}{ DATA UMUM } \\
\hline No & & 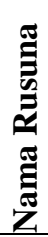 & 莺 & & $\begin{array}{l}\frac{\pi}{0} \\
\frac{0}{d 0} \\
\frac{00}{0} \\
0\end{array}$ & 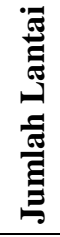 & 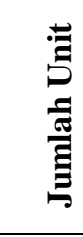 & 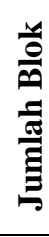 \\
\hline 9 & Bidaracina & & 12 & DKI & & 5 & 688 & 7 \\
\hline 10 & Karet Tengsin & & 11 & DKI & & 5 & 160 & 4 \\
\hline 11 & Kebon Kacang & & 24 & Perumnas & & 4 & 664 & 8 \\
\hline 12 & Pulo Gebang (Seruni) & & 6 & Perumnas & & 5 & 240 & 4 \\
\hline 13 & Tebet I & & 13 & DKI & & 5 & 340 & 4 \\
\hline 14 & Pulo Gadung & & 16 & Perumnas & & 4 & 160 & 2 \\
\hline
\end{tabular}

Survei kondisi fisik dilakukan untuk memetakan pola kerusakan kinerja fisik atap dengan penentuan tingkat kerusakan berdasarkan skala likert.

Tabel 2. Penilaian kondisi fisik komponen atap rumah susun

\begin{tabular}{|c|c|c|c|}
\hline $\begin{array}{c}\text { Tingkat } \\
\text { Kerusakan } \\
\text { (Rating) }\end{array}$ & $\begin{array}{l}\text { Prosentase } \\
\text { Kerusakan } \\
\quad(\%)\end{array}$ & Uraian & Rekomendasi \\
\hline 7 (Excellent) & $0-10$ & Komponen atap masih baru & - \\
\hline 6 (Very Good) & $11-25$ & $\begin{array}{l}\text { Komponen atap umumnya baru atau baru di } \\
\text { diperbaiki, komponen tersebut tidak menunjukan } \\
\text { tanda-tanda deterioration, seperti: keropos, retak- } \\
\text { retak, jamuran, dll. }\end{array}$ & $\begin{array}{l}\text { Perawatan \& pemeliharaan } \\
\text { berkala }\end{array}$ \\
\hline 5 (Good) & $26-40$ & $\begin{array}{l}\text { Komponen atap menunjukkan kerusakan yang } \\
\text { tidak disengaja, kerusakan kecil (minor defect), } \\
\text { adanya tanda-tanda (minor) yang menunjukkan } \\
\text { deterioration dipermukaannya dan menyarankan } \\
\text { untuk dirawat/ diservis. Hal tersebut dapat } \\
\text { dikembalikan kondisinya dengan maintenance } \\
\text { yang terjadwal maupun yang tidak terjadwal. }\end{array}$ & $\begin{array}{l}\text { Perawatan dan perbaikan } \\
\text { berkala }\end{array}$ \\
\hline 4 (Fair) & $41-55$ & $\begin{array}{l}\text { Komponen atap membutuhkan perbaikan yang } \\
\text { dilakukan oleh spesialis. Komponen atap } \\
\text { dinyatakan tidak layak digunakan lagi, karena } \\
\text { kerusakan telah berdampak kepada komponen } \\
\text { lain di sekelilingnya. Penyebabnya adalah } \\
\text { tertundanya pekerjaan maintenance (backlog } \\
\text { maintenance work). }\end{array}$ & Perbaikan minor \\
\hline 3 (Average) & $56-70$ & $\begin{array}{l}\text { Komponen atap mengalami proses deterioration } \\
\text { yang buruk dan dapat mengurangi fungsi } \\
\text { bangunan. Diperlukan perbaikan (repair) dan } \\
\text { bilamana perlu rehabilitasi. }\end{array}$ & $\begin{array}{l}\text { Harus dilakukan diperbaiki, } \\
\text { jika perlu komponen diganti }\end{array}$ \\
\hline 2 (Marginal) & $71-85$ & $\begin{array}{l}\text { Komponen atap mengalami deterioration yang } \\
\text { sangat buruk, yang membutuhkan renovasi. } \\
\text { Umumnya secara fungsional atap dapat } \\
\text { dinyatakan gagal, yang berdampak terhadap risiko } \\
\text { kesehatan dan keselamatan. Diperlukan } \\
\text { rehabilitasi yang serius. }\end{array}$ & $\begin{array}{l}\text { Komponen atap dipersyaratkan } \\
\text { untuk diganti }\end{array}$ \\
\hline 1 (Poor) & $\geq 85$ & $\begin{array}{l}\text { Komponen atap harus diganti dan dinyatakan } \\
\text { gagal (buruk). }\end{array}$ & Komponen atap harus diganti \\
\hline
\end{tabular}

Pada tahap 2 dilakukan metode Delphi untuk mengetahui faktor-faktor penyebab menurunnya kinerja fisik atap menurut penilaian pakar. Metode Delphi dilakukan melalui dua tahap. Pada tahap pertama dilakukan penilaian para partisipan terhadap faktor-faktor penyebab menurunnya kinerja fisik komponen atap. Sedangkan pada tahap kedua dilakukan validasi terhadap jawaban partisipan tersebut. Metode Delphi melibatkan 47 partisipan yang pernah terlibat langsung dalam proyek rumah susun sederhana, baik sebagai peneliti, perancang, perencana, kontraktor, dan pengelola. 


\section{HASIL DAN PEMBAHASAN}

Komponen atap yang dimaksud dalam tulisan ini meliputi: kuda-kuda, gording, kaso, reng, penutup atap dan lisplang. Hasil penilaian berdasarkan rating yang telah ditentukan menunjukkan bahwa kuda-kuda (K1.1) pada 1 bangunan (Tanah Abang) bernilai 2, berarti komponen tersebut sudah mengalami kinerja fisik yang sangat buruk. Kuda-kuda pada 5 bangunan lainnya bernilai 3 (komponen tersebut mengalami kinerja fisik yang buruk), yaitu: Bendungan Hilir, Bidaracina, Kebon Kacang, Klender, dan Pulo Gadung. Secara keseluruhan rata-rata kondisi fisik kuda-kuda atap adalah 3,7 (masih dibawah ambang batas), berarti komponen tersebut sudah mengalami degradasi dan membutuhkan perawatan dan perbaikan.

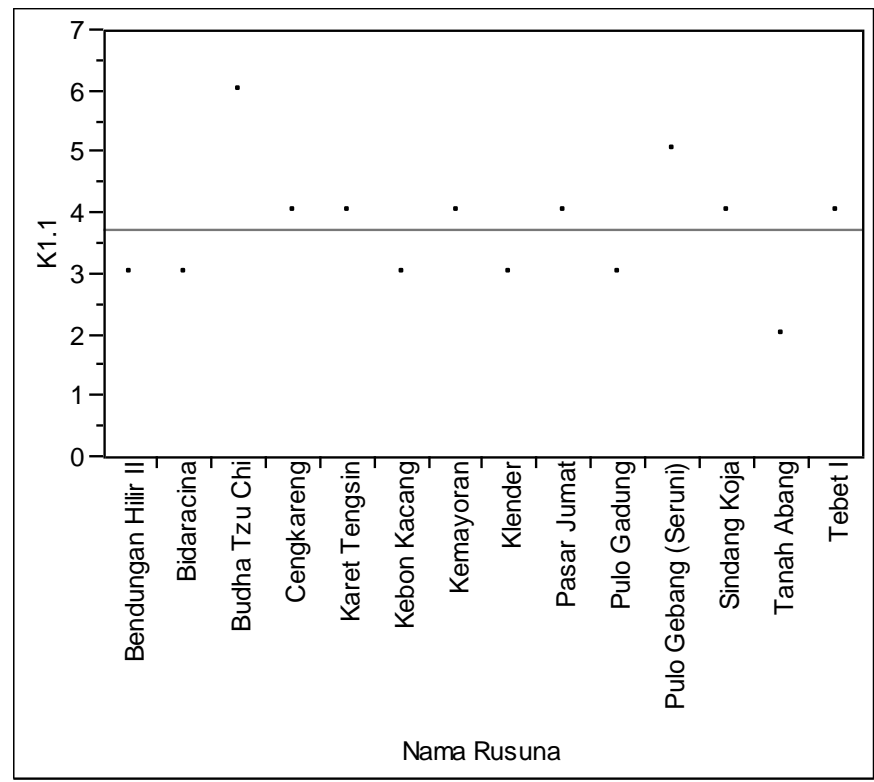

$\mathrm{K} 1.1$ = Rating kondisi fisik kuda-kuda

\section{Gambar 1. Kondisi fisik kuda-kuda}

Kondisi fisik gording pada rumah susun sederhana Tanah Abang sudah mengalami degradasi yang sangat buruk (bernilai 2). Kondisi gording pada 5 bangunan rumah susun sederhana lainnya mempunyai nilai 3, yaitu: Bendungan Hilir II, Bidaracina, Kebon Kacang, Klender, Pulo Gadung, dan Tanah Abang. Rata-rata kondisi fisik gording adalah 3,7 (di bawah ambang batas) (gambar 2).

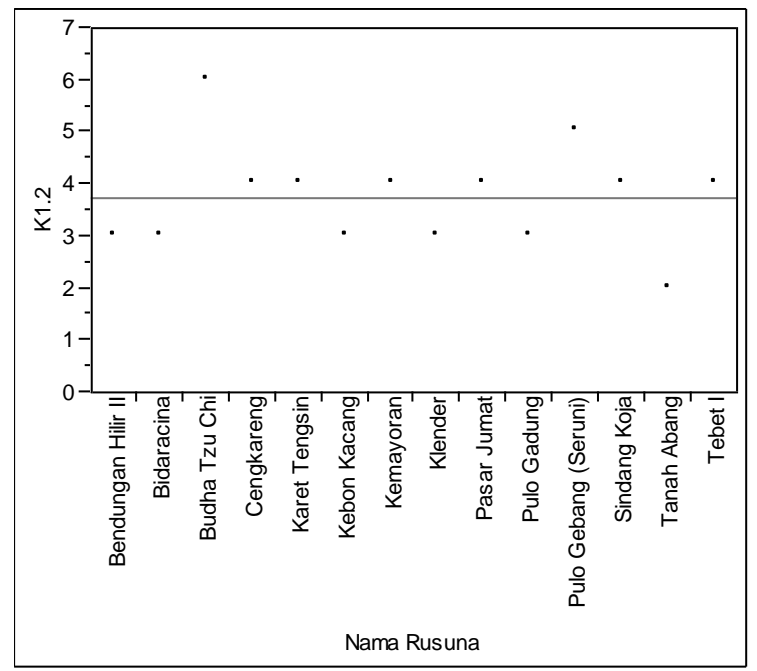

K1.2 = Rating kondisi fisik gording

Gambar 2. Kondisi fisik gording 
Kondisi fisik kaso sama dengan kondisi fisik gording (gambar 3). Kondisi fisik kaso Tanah Abang mempunyai nilai yang paling rendah yaitu 2. Rata-rata kondisi fisik kaso adalah 3,7 (di bawah ambang batas).

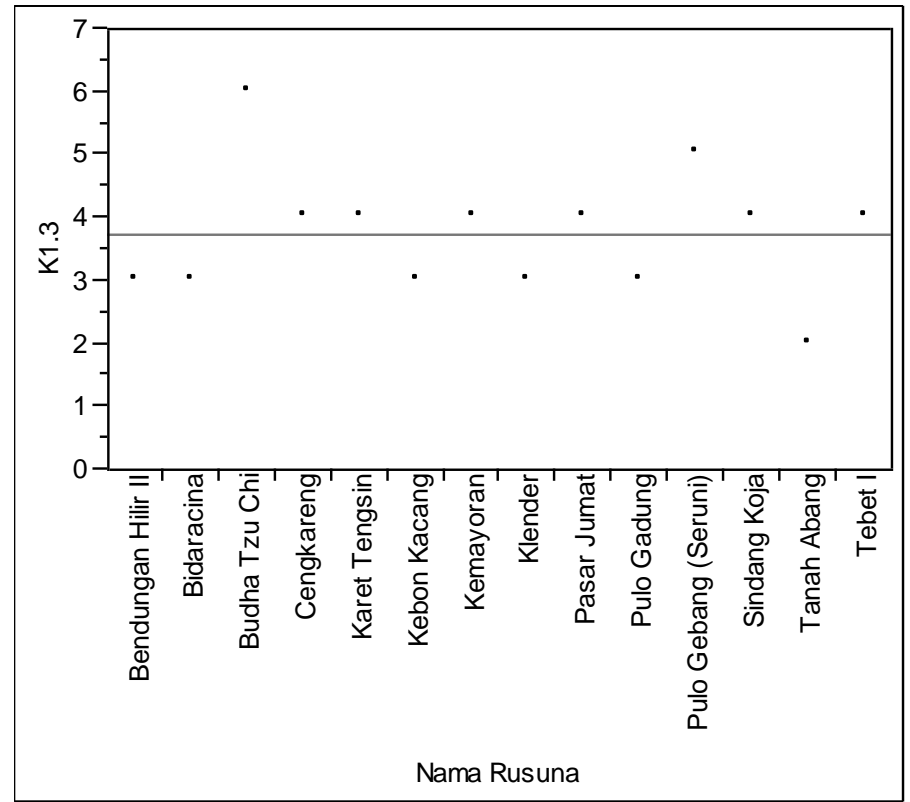

$\mathrm{K} 1.3$ = Rating kondisi fisik kaso

Gambar 3. Kondisi fisik kaso

Kondisi fisik reng (K1.4) sama dengan kondisi fisik kaso dan gording (gambar 4). Kondisi fisik reng rumah susun sederhana Tanah Abang mempunyai nilai yang paling rendah yaitu 2. Rata-rata kondisi fisik reng adalah 3,7 (di bawah ambang batas).

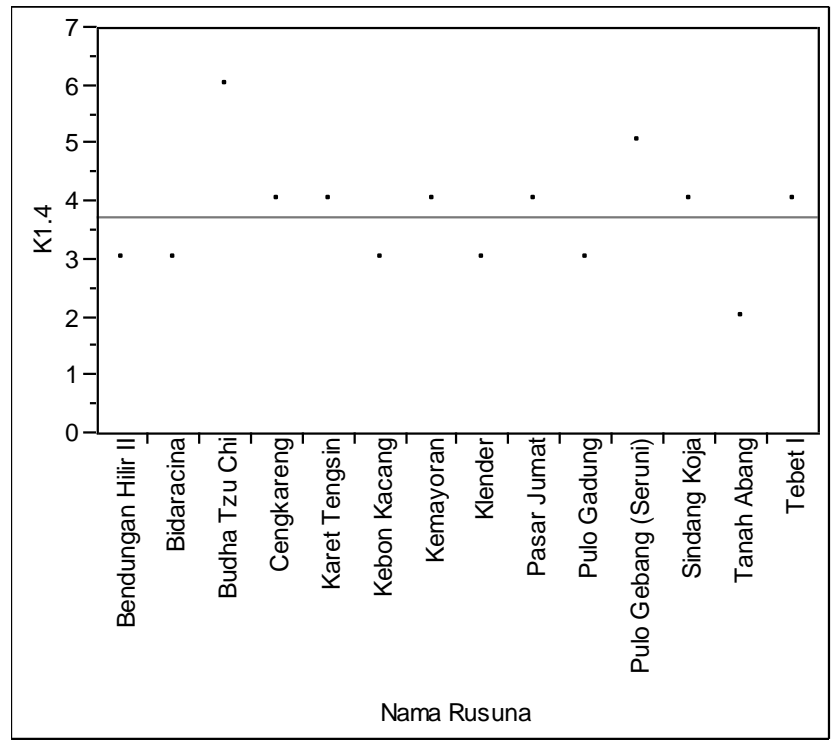

$\mathrm{K} 1.4$ = Rating kondisi fisik reng

\section{Gambar 4. Kondisi fisik reng}

Kondisi fisik penutup atap sangat tergantung pada jenis dan kualitas material penutup atap tersebut. Rating kondisi fisik penutup atap cukup buruk, dengan nilai rata-rata 3,57 (gambar 5). Lima rumah susun sederhana mempunyai nilai kondisi fisik penutup atap 2, 
yaitu: Bidaracina, Kebon Kacang, Klender, Pulo Gadung, dan Tanah Abang.

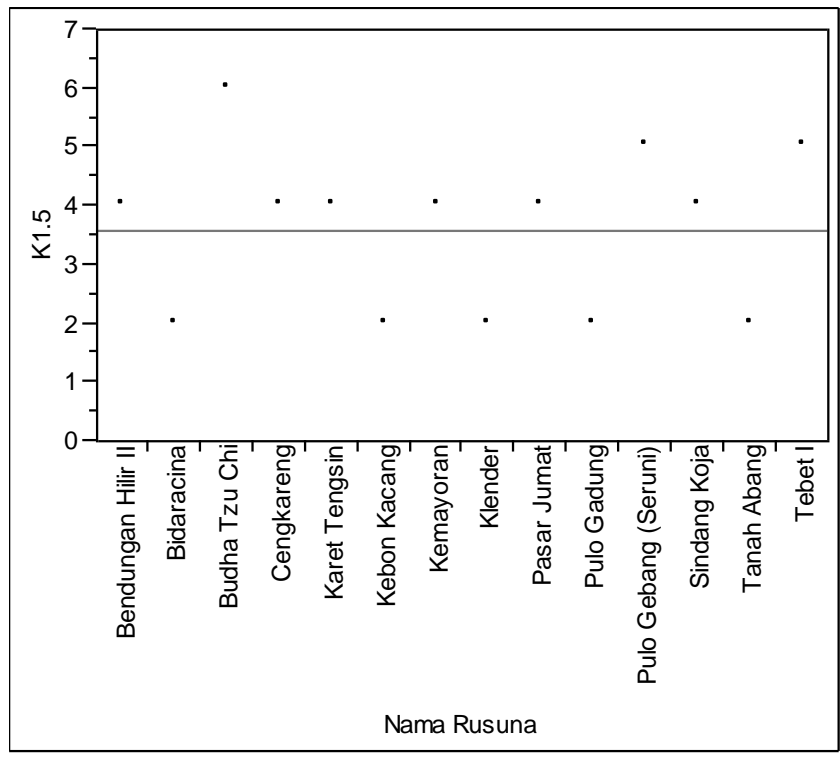

K1.5 = Rating kondisi fisik penutup atap

Gambar 5. Kondisi fisik penutup atap

Kondisi fisik lisplang sangat buruk (nilai rata-rata 2,64), menunjukkan bahwa komponen tersebut harus segera diperbaiki atau dipersyaratkan untuk diganti. Tiga rumah susun sederhana mempunyai nilai kondisi fisik lisplang sangat buruk dan harus diganti (nilai 1), yakni: Kebon Kacang, Klender, dan Tanah Abang. Tiga rumah susun sederhana yang mempunyai nilai 3 (komponen harus diperbaiki dan jika perlu komponen diganti) adalah: Bendungan Hilir II, Bidaracina, dan Pulo Gadung (gambar 6).

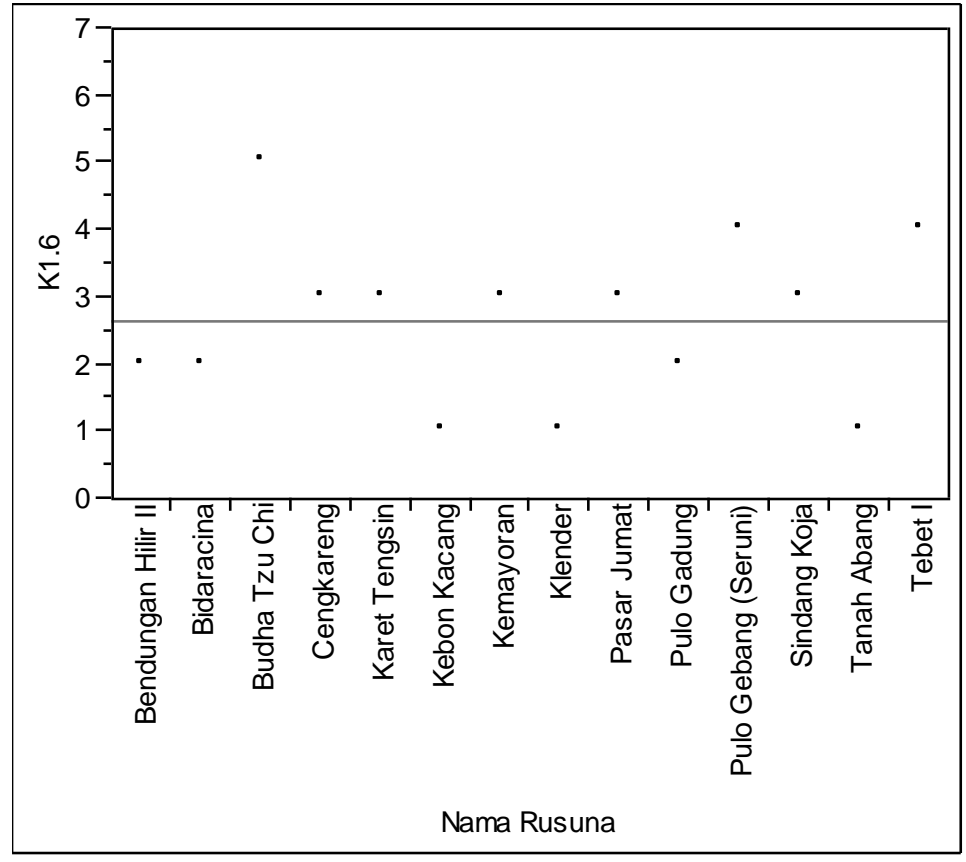

K1.6 = Rating kondisi fisik lisplang

Gambar 6. Kondisi fisik lisplang

Rumah susun sederhana Budha Tsu Zhi memiliki rating yang paling tinggi untuk komponen atap, bila dibandingkan dengan rumah susun sederhana lainnya. Sedangkan rumah 
susun Tanah Abang mempunyai nilai yang paling rendah, yaitu rata-rata 2 dan bahkan 1 untuk lisplang (gambar 6). Bila diperbandingkan dari segi umur bangunan, kedua rumah susun sederhana tersebut perbedaannya sangat jauh. Rumah susun sederhana Budha Tsu Zhi baru berumur 5 tahun, sedangkan rumah susun Tanah Abang sudah berumur 26 tahun. Terdapat beberapa rumah susun sederhana yang mempunyai umur sama atau bahkan lebih tinggi, tetapi kondisi fisik komponen atapnya lebih buruk. Sebagai contoh, rumah susun sederhana Bidaracina yang umurnya 12 tahun mempunyai kondisi fisik komponen atap lebih rendah dari pada rumah susun sederhana Kemayoran yang umurnya 16 tahun dan Cengkareng yang umurnya sama 12 tahun.

Perbedaan umur bangunan dan kondisi komponen atap antara lain disebabkan oleh beberapa faktor, yaitu: 1) Kualitas komponen atap yang digunakan. Material penutup atap yang digunakan rumah susun Cengkareng mempunyai kualitas yang lebih baik dari rumah susun sederhana Bidaracina, 2) Kualitas perawatan. Peranan pengelola (lembaga terkait atau masyarakat) merupakan faktor kunci yang menyebabkan kondisi komponen atap baik. Rumah susun sederhana Bidaracina tidak memiliki pengelola dan penghuninya s tidak terlalu peduli dengan kondisi bangunannya, sedangkan pada rumah susun sederhana Cengkareng dan Kemayoran, peran aktif Perumnas sebagai pengelola menyebabkan kondisi komponen atap cukup baik.

Dari hasil pengamatan terhadap kondisi fisik atap di atas, dapat diketahui hubungan antara umur dan kondisi fisik komponen atap setiap rumah susun sederhana, dengan persamaan regresi sebagai berikut: Kondisi fisik atap $=5,5343822-0,150713 *$ Umur + 0,0067488*(Umur-13,7857)^2. Semakin tinggi umur, kinerja fisik komponen atap cenderung semakin buruk.

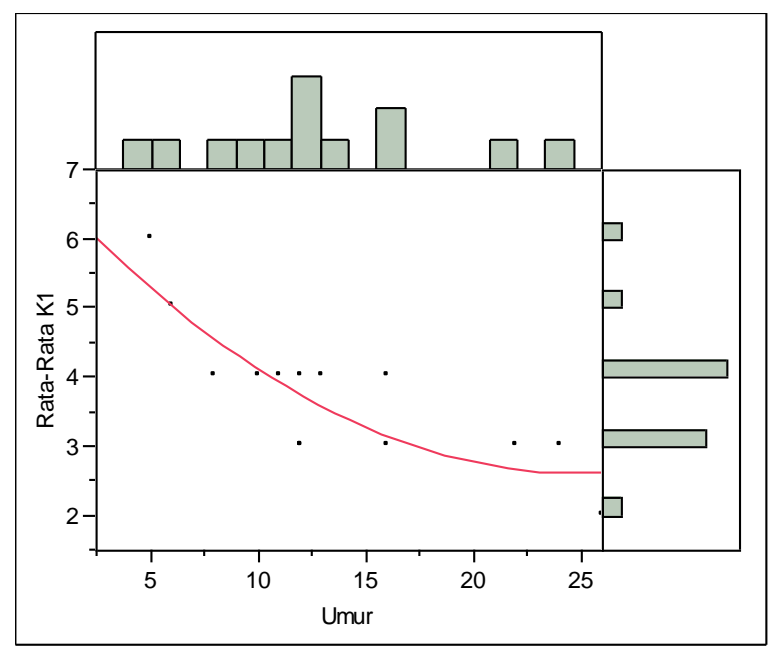

\section{Gambar 7. Persamaan kinerja fisik komponen atap}

Rsquare bernilai 0,723975, menunjukkan bahwa kinerja fisik dan umur bangunan mempunyai korelasi yang signifikan. Berdasarkan gambar 7 dapat diketahui bahwa penurunan kinerja fisik komponen atap telah dimulai pada umur 10 tahun, padahal umur yang direncanakan untuk bangunan tersebut adalah 30 tahun. Dapat disimpulkan bahwa komponen atap sudah buruk kondisi fisiknya sebelum mencapai umur bangunan yang ditentukan.

Seperti telah diuraikan sebelumnya, terdapat 6 faktor yang mempengaruhi kondisi komponen atap (AIJ, 1993; ISO 1686-1, 2000), yaitu: kualitas material, kualitas desain, kualitas pengerjaan, kualitas lingkungan (iklim), kualitas penggunaan, dan kualitas perawatan. Untuk mengetahui faktor-faktor penyebab kerusakan fisik komponen atap, penilaian dari para pakar dijaring melalui metode Delphi yang terdiri dari 2 tahap. Delphi 
tahap 1 dilakukan untuk mengetahui faktor-faktor penyebab kerusakan fisik (menggunakan skala likert $1-5$ ), serta alasan para pakar memilih setiap faktor penyebab tersebut. Pada Delphi 2 partisipan diminta untuk mengkonfirmasi kembali faktor-faktor penyebab tersebut (berdasarkan masukan dari Delphi 1).

Dari 47 partisipan, terdapat 18 partisipan yang memberikan masukan tambahan terhadap faktor-faktor, tetapi setelah dianalisis lebih lanjut, masukan dari ke-18 partisipan tersebut ternyata sudah termasuk dalam lingkup 6 faktor yang ditentukan. Sebagai contoh, partisipan memberikan tambahan faktor mutu material, padahal faktor tersebut sudah menjadi bagian dari faktor A (kualitas material) atau beberapa responden menyatakan buruknya tukang, padahal faktor tersebut sudah termasuk dalam faktor C (kualitas pengerjaan).

Menurut penilaian para pakar, urutan faktor-faktor pengaruh adalah seperti pada Tabel 3.

Tabel 3. Pengaruh faktor-faktor terhadap komponen atap

\begin{tabular}{llrrrrrrr}
\hline & \multicolumn{2}{l}{ K1A } & \multicolumn{1}{l}{ K1B } & K1C & K1D & K1E & K1F \\
\hline $\mathrm{N}$ & Valid & 47 & 47 & 47 & 47 & 47 & 47 \\
\cline { 2 - 10 } & Missing & 0 & 0 & 0 & 0 & 0 & 0 \\
\hline Mean & 4.83 & 3.98 & 4.72 & 3.38 & 2.96 & 4.23 \\
\hline Mode & 5 & 4 & 5 & 3 & 3 & 5 \\
\hline Std. Deviation & .524 & .847 & .615 & 1.074 & 1.062 & .983 \\
\hline
\end{tabular}

Keterangan:

$\mathrm{K} 1 \mathrm{~A}=$ Komponen atap pengaruh faktor $\mathrm{A}$ (kualitas material)

$\mathrm{K} 1 \mathrm{~B}=$ Komponen atap pengaruh faktor B (kualitas desain)

$\mathrm{K} 1 \mathrm{C}=$ Komponen atap pengaruh faktor $\mathrm{C}$ (kualitas pengerjaan)

$\mathrm{K} 1 \mathrm{D}=$ Komponen atap pengaruh faktor $\mathrm{D}$ (kualitas lingkungan luar)

$\mathrm{K} 1 \mathrm{E}=$ Komponen atap pengaruh faktor $\mathrm{E}$ (kualitas penggunaan)

$\mathrm{K} 1 \mathrm{~F}=$ Komponen atap pengaruh faktor $\mathrm{F}$ (kualitas perawatan)

Urutan besarnya faktor pengaruh adalah sebagai berikut: 1) faktor kualitas material (mean: 4,83), 2) faktor pengerjaan (mean: 4,72), 3) faktor kualitas perawatan (mean: 4,23), 4) faktor kualitas desain (mean: 3,98), 5) faktor kualitas lingkungan (iklim) (mean: 3,38), dan 6) faktor peggunaan (mean: 2,96). Gambaran tentang pengaruh secara keseluruhan dapat dilihat pada gambar 8, yang didis-agregasikan berdasarkan keterlibatan partisipan sebelumnya dalam tahap proyek perumahan.

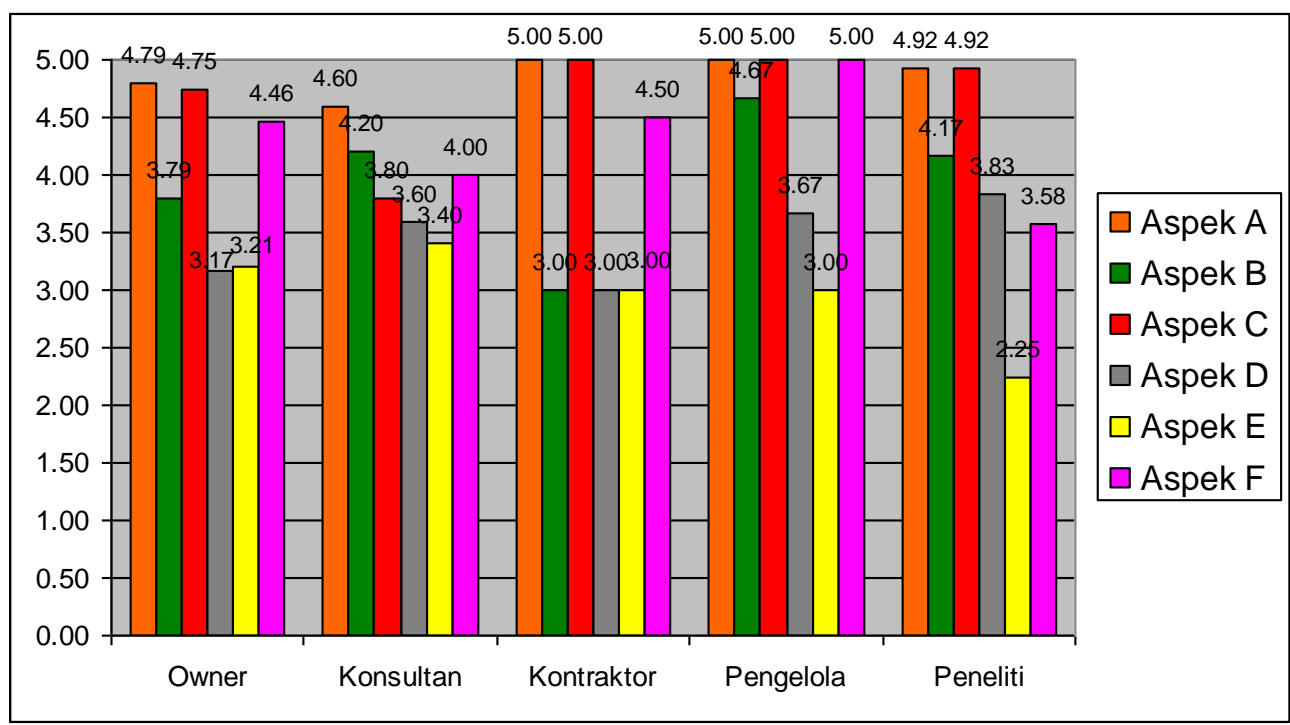

Gambar 8. Tingkat pengaruh faktor-faktor menurut partisipan 
Menurut beberapa partisipan, komponen atap rumah susun sederhana seharusnya menggunakan material yang terbaik supaya umurnya lama, mengingat lemahnya sistem pengelolaan dan perawatan pada rumah susun sederhana. Alasan lain karena masyarakat penghuni rumah susun bersifat heterogen, sehingga komunikasi dan koordinasi perawatan ataupun perbaikan kerusakan komponen atap sulit dilaksanakan. Kualitas pengguna merupakan faktor yang nilainya paling rendah. Hal ini dapat dipahami, karena hanya penghuni lantai teratas yang berkaitan langsung dengan komponen atap. Beberapa partisipan melaporkan bahwa kerusakan kommponen atap di beberapa rusun terjadi akibat perilaku penghuni yang memanjat ataupun menginjak atap untuk memasang antenna, menjemur pakaian, mengecat atau memperbaiki jendela dan dinding pada lantai 2 sampai lantai 5.

Meski nilai yang diberikan partisipan untuk setiap komponen berbeda-beda, tetapi terdapat pola yang tipikal. Penyebab faktor material adalah: 1) mutu material $(4,83), 2)$ jenis material $(4,46), 3)$ biaya material $(4,24), 4)$ kesesuaian dengan lingkungan $(3,74)$, dan 5) kesesuaian dengan sistem bangunan $(3,61)$. Hal ini menunjukkan bahwa untuk komponen atap, mutu material menurut responden menjadi pertimbangan utama. Penyebab faktor kualitas desain adalah: 1) mutu material $(4,83), 2)$ jenis material $(4,46), 3)$ biaya material $(4,24), 4)$ kesesuaian dengan lingkungan $(3,74)$, dan 5) kesesuaian dengan sistem bangunan $(3,61)$. Menurut 47 partisipan, mutu material, jenis material, dan biaya merupakan faktor yang saling berkaitan erat. Jika biaya yang tersedia cukup besar, maka mutu dan jenis material dapat ditingkatkan.

Menurut pendapat para partisipan, kualitas pengerjaan komponen atap dipengaruhi oleh kualitas pekerja (tukang) dan kualitas kontraktor. $72 \%$ partisipan menyatakan bahwa kualitas tukang di Indonesia (khususnya yang terlibat dalam pembangunan rumah susun sederhana) masih sangat rendah. Andil para kontraktor dalam hal ini sangat besar, karena merekalah yang memilih tukang. Faktor yang dinilai paling signifikan mempengaruhi kualitas material komponen atap adalah curah hujan, temperatur, serta kelembaban. Menurut para partisipan, masalah kualitas lingkungan luar dapat diatasi dengan meningkatkan kualitas material, pengerjaan, dan perawatan.

Lemahnya kepranataan dan kurangnya kesadaran penghuni merupakan dua faktor yang paling mempengaruhi aspek penggunaan. Kepatuhan penghuni rumah susun sederhana pada peraturan yang berlaku sangat lemah. Faktor perawatan menurut responden merupakan salah satu pertimbangan yang harus diperhatikan di dalam penjaminan kinerja komponen atap bangunan rumah susun sederhana. Faktor-faktor yang mempengaruhi faktor kualitas perawatan adalah biaya perawatan dan kualitas pengelola. Biaya perawatan merupakan faktor yang selama ini menjadi masalah di dalam perawatan rumah susun sederhana. Berdasarkan hasil studi lapangan terhadap 14 rumah susun, tidak ada biaya yang dikeluarkan penghuni untuk perawatan. Perawatan hanya dilakukan jika ada komponen yang rusak, padahal perawatan menjadi prasyarat untuk menjamin tercapainya umur komponen bangunan yang direncanakan.

\section{SIMPULAN DAN SARAN}

Pola kerusakan fisik komponen atap pada bangunan rumah susun sederhana di DKI Jakarta terjadi pada umur 10 tahun. Kerusakan tersebut disebabkan oleh berbagai faktor, meliputi: kualitas material, kualitas desain, kualitas pengerjaan, kualitas lingkungan luar (iklim), kualitas pengelola, dan kualitas perawatan. Terdapat 3 faktor yang paling mempengaruhi kinerja fisik komponen atap, yaitu: (1) Faktor material komponen atap, faktor yang perlu diperhatikan untuk penentuan material komponen atap adalah mutu material, jenis material, dan biaya material. (2) Faktor kualitas pengerjaan, faktor yang perlu diperhatikan untuk penentuan kualitas pengerjaan komponen atap adalah kualitas pekerja (tukang) dan 
kontraktor. (3) Faktor kualitas perawatan, faktor yang perlu diperhatikan untuk penentuan kualitas perawatan komponen atap adalah biaya perawatan dan kualitas pengelola.

\section{DAFTAR RUJUKAN}

De Wilde, Pieter. (2018). Building performance analysis. UK: John Wiley \& Sons.

Oduyemi, O., \& Okoroh, M. (2016). Building performance modelling for sustainable building design. International Journal of Sustainable Built Environment, 5(2), 461-469.

Trinius, W., \& Sjöström, C. (2005), Service life planning and performance requirements, Building research \& information, 33(2), 173-181.

ISO 15686-1 (2000), Buildings and Construction Assets-Service Life Planning-Part 1: General Principles, Geneva: International Standard Organisations.

Marteinsson, B. (2003), "Durability and the Factor Method of ISO 15686-1", Building Research \& Information 31(6): 416-426.

Hernández-Moreno, S. (2011). Importance of Service Life Planning In Sustainable Architecture. Management Research \& Practice, 3(3).

Marteinsson, Bjoern \& Jónsson, B., 1999, "Overall Survey of Buildings - Performance and Maintenance", Proceeding 8th Durability of Building Materials and Components, Institute for Research in Construction, Ottawa, Canada, pp. 1634-1654.

Mc Duling, J.J. (2005), Towards the Development of Transition Probability Matrices in the Markovian Model for the Predicted Service Life of Buildings, PhD Thesis, Department of Civil and Biosystems Engineering, Faculty of Engineering, Built Environment and Information Technology, University of Pretoria, South Afrika

Preiser, Wolfgang F.E. (2005), Assessing Building Performance, USA: University of Cincinnati Press

Shohet, I.M, Paciuk, Monika. (2004). "Service Life Prediction of Exterior Cladding Components under Failure Conditions", Construction Management and Economic (24:2): 131-148. 